\title{
A zöldség-, gyümölcs- és hüvelyesek fogyasztása és a kardio- vaszkuláris betegségek és halandóság 18 országban (PURE): prospektív kohorsz vizsgálat
}

\author{
Fruit, vegetable, and legume intake, and cardiovascular disease and deaths \\ in 18 countries (PURE): a prospective cohort study
}

Ismertető: Bakacs Márta $\bowtie$

Országos Gyógyszerészeti és Élelmezés-egészségügyi Intézet

Szerzők: Miller V, Mente A, Dehghan M et al.

Megjelenés: The Lancet, Published Online August 29, 2017. DOI: http://dx.doi.org/10.1016/S0140-

6736(17)32253-5

Beküldve: 2017.09.13.

doi: $10.24365 /$ ef.v58i3.178

Kulcsszavak: gyümölcs,- zöldség- és hüvelyes-fogyasztás, kardiovaszkuláris és összhalálozás, regressziós modell, egyéni és környezeti tényezők, kockázatcsökkenés

\section{ÖSSZEFOGLALÁS}

Prospektív kohorsz vizsgálatban 135 335, 35-70 év közötti, kardiovaszkuláris betegségtől mentes ember követését indították el 2003 és 2013 között Észak- és Dél-Amerika, Európa, Közel-Kelet, Dél- és Délkelet-Ázsia, Kína és Afrika 18 eltérő jövedelmű országában. Adatokat gyűjtöttek a résztvevők táplálkozásáról, társadalmi-gazdasági helyzetéről, életmódjáról, betegségeiről valamint a kardiovaszkuláris betegségek családi halmozódásáról. Egy egyszerúbb és egy sokváltozós regressziós modellel vizsgálták a zöldség-, gyümölcs- és hüvelyes-fogyasztás összefüggését a kardiovaszkuláris betegségekkel illetve a halálozással.
Az alapmodell eredményei szerint a magasabb gyümölcs-, zöldség- és hüvelyes-fogyasztás csökkentette a kardiovaszkuláris betegségek, a szívinfarktus, a kardiovaszkuláris és nem-kardiovaszkuláris mortalitás valamint az összhalálozás kockázatát is. Az összefüggések erőssége azonban jelentősen gyengült, amikor az összetettebb regressziós elemzéssel kiszűrték a számos egyéni és környezeti befoIyásoló tényező hatását: csupán a nem-kardiovaszkuláris és az összhalálozás kockázatcsökkenése volt megfigyelhető. Ugyanakkor e két utóbbi végpont esetén már a napi 3-4 adag gyümölcs-, zöldség- és hüvelyes fogyasztása is maximális kockázatcsökkenést mutatott.

\section{KULCSÜZENET A SZAKEMBEREK SZÁMÁRA}

A közlemény is alátámasztja, az egészségmagatartás vizsgálata során figyelembe kell venni az egyéni és környezeti tényezők hatásait. Továbbá, az ajánlásoknak megfelelő zöldség-, gyümölcs- és hüvelyes-fogyasztás kultúrájának általánossá válása Magyarországon nemcsak az elhízás, hanem számos betegség kockázatát is csökkentené. 